\title{
InVESTigation OF Stimulated Bag-Breakup Processes in Laboratory MODELING OF WIND-WAVE INTERACTION
}

\author{
Alexander Kandaurov ${ }^{1}$; Daniil Sergeev ${ }^{2}$; Yuliya Troitskaya ${ }^{3}$ \\ Institute of Applied Physics RAS, Geophysical Research Division, \\ 603950 Ulyanova st. 46, Nizhny Novgorod, Russia \\ e-mail: ${ }^{1}$ kandaurov@ @ydro.appl.sci-nnov.ru; ${ }^{2}$ sergeev4758@ gmail.com; \\ yuliya@hydro.appl.sci-nnov.ru
}

\begin{abstract}
The laboratory experiments for identification of mechanisms of the spume droplet's formation in marine atmospheric boundary layer, when strong wind tears off water from the crest of the waves, were carried out at the High-speed wind-wave flume of IAP RAS. The main mechanism responsible for the generation of spume droplets is bag breakup fragmentation of small-scale disturbances that arise at the air-water interface under the strong wind. This work concentrates on investigation of a separate bag-breakup event that was forced to occur in a dried high-speed wind-wave flume. The details of the bag-breakup fragmentation were investigated qualitatively and quantitatively using synchronized multiperspective high-speed video recording in shadowgraph configuration.
\end{abstract}

\section{Keywords}

Wind-wave interaction; Atmospheric boundary layer; Wind-wave flume; Sea spray; Bagbreakup; High-speed video; Particle tracking velocimetry.

\section{Introduction}

Sea sprays are typical element of the marine atmospheric boundary layer and important environmental effect. Difficulties of direct measurements in hurricane conditions and insufficient knowledge about the mechanisms of the spume droplet's formation are the main reasons for insufficient knowledge on the sea spray generation function, which characterizes the size distribution of droplets injected from a unit of surface in a unit of time, leading to significant uncertainties in estimations of sea sprays influence on the marine atmospheric boundary layer [1-6]. For example, the empirical function of spray generation may differ by six orders of magnitude based on different observation reports (see a review of experimental data in [7]). Even the spray-generation mechanisms in extreme winds remained undetermined $[4,7]$.

The laboratory experiments for identification of these mechanisms, when strong wind tears off water from the crest of the waves, were carried out at the High-speed wind-wave flume of IAP RAS. As previous studies showed based on statistical analysis of number of these phenomena at different winds, the main mechanism responsible for the generation of spume droplets is bag-breakup fragmentation of small-scale disturbances that arise at the air-water interface under the strong wind [8]. This regime is characterized by inflating and consequent bursting of the short-lived objects, bags. It begins with increase of small-scale elevation of the surface, transforming to small "sails" then inflated to a water film bordered by a thicker rim and at last blows up, so the droplets are produced from rupture of the water film and fragmentation of the rim. 
One of the most important problems, we are trying to solve, is to construct the spray generation function as the basis for calculating the contribution of spray to exchange processes at the air-sea interface. In our previous work [8], the statistics on bag-breakup events have already been found as a result of processing high-speed recordings of the water surface at high winds in flume. To build the spray generation function, we need to know in addition what droplets are formed during one bag-breakup fragmentation. Then the spray generation function can be found as convolution of the of "bag" generation function and of the distribution function of droplets from one "bag-breakup". In this model experiment, we develop methods for obtaining this distribution for a single "bag". The spontaneous characterization of their occurrence on the water surface complicated detailed studies, and in this work we study the separate bag-breakup event that was forced to occur in a dried highspeed wind-wave flume.

The first part of the article is devoted to the description of the methodology of experiments at high-speed wind-wave flume. The second part describes how high-speed video recordings of "bags" were processed to obtain spray characteristics. The work is summarized in conclusion.

\section{$1 \quad$ Experiment and Measurements}

\subsection{High-Speed Wind-Wave Flume}

The experiments were performed in the High-speed wind-wave flume located on top of the Large Thermostratified Tank (LTST) of the Institute of Applied Physics (IAP RAS). The centrifugal fan equipped with an electronic frequency converter to control the discharge rate of the airflow produced the airflow in the flume with the straight working part of $10 \mathrm{~m}$. The operating cross section of the airflow is $0.4 \times 0.4 \mathrm{~m}^{2}$. During the experiments axis velocity in the flume varied from 10 to $17 \mathrm{~m} / \mathrm{s}$. More details of the facility construction and parameters of air flow and surface waves are described in [9]. As this work concentrates on generation and investigations of a separate bag-breakup event, the flume was closed at its bottom with rigid plates at the water level used in previous experiments [8] and bag-breakup event was forced to occur at a small reservoir installed at a distance of $7.5 \mathrm{~m}$ from the beginning of the working section. The measured value of the surface tension was $\sigma=(7.0 \times 0.15) \cdot 10^{-2} \mathrm{~N} / \mathrm{m}$. The principal scheme of the experimental setup is shown in Fig. 1.

\section{Legend}

1 - LED lights,

2 - solid flat bottom,

3 - opaque screen,

4 - high-speed wind-wave flume,

5 - top high-speed camera,

6 - bag-breakup,

7 - side semi-submerged box,

8 - side high-speed camera,

9 - nozzle,

10 - reservoir with water,

11 - foam rubber in water, 12 - nylon mesh.

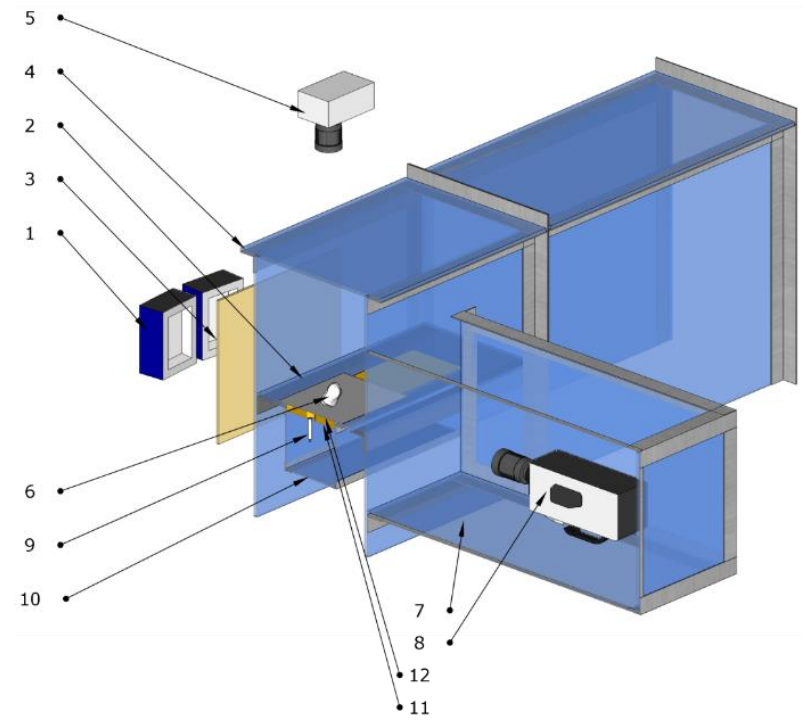

Fig. 1: The cross-section of the high-speed wind-wave flume 


\subsection{Initial Disturbance}

Initial disturbance from which the bag breakup developed was artificially created at the desired position using the underwater jet from a submerged nozzle. The nozzle was placed in vertical orientation $15 \mathrm{~cm}$ under water surface. It is assembled of 5 nickel tubes $20 \times 2 \mathrm{~mm}$, lined up in a row in cross-wind direction. Water entered the nozzle at a pressure of 3 bar via an electronically controlled valve that was opened for a period of $20 \mathrm{~ms}$. Driving signal for the valve was combined with triggers of both cameras in synchronization system, controlled via microcontroller.

In order to damp the disturbances that arise on the surface of the water a sheet of $20 \mathrm{~mm}$ thick foam rubber with a hole $30 \mathrm{~mm}$ in diameter was placed above the nozzle. It was additionally covered with a nylon net with cell size $2 \mathrm{~mm}$. The aim was to inject about $2.5 \mathrm{ml}$ of water in $20 \mathrm{~ms}$ with good repeatability. The dependence of the shape of the initial disturbance on time was investigated using image processing of frames from the side camera captured without wind. Comparison of successive initial disturbances showed the stability of their shape within $10 \%$ for height and diameter.

\subsection{Wind Flow Parameters}

The wind flow parameters were measured by the profile method at a distance of $7.5 \mathrm{~m}$ from the beginning of the flume. Wind velocity profiles were measured by the L-shaped Pitot tube with the differential pressure transducer Baratron MKS 226A with the accuracy of $0.5 \%$ of full scale range, i.e., $3 \mathrm{~cm} / \mathrm{s}$. The tube was mounted on the scanning device. The lower level of scanning located at a distance of $1 \mathrm{~cm}$ from the surface, while the upper layer was $20 \mathrm{~cm}$. The scanning method with the slow continuous vertical movement of $1.1 \mathrm{~mm} / \mathrm{s}$ was used. The results were binned into 100 equidistant levels. For each fixed wind parameters, at least five profiles were measured for subsequent averaging. This technique allowed obtaining wind speed profiles in logarithmic boundary layer and calculate the friction velocity and equivalent speed at a standard meteorological height of $10 \mathrm{~m}$. The scaling parameter for the air turbulent boundary layer flow above the water surface is the friction velocity, $u_{*}^{*}$, defined via vertical turbulent shear stress: $F_{\mathrm{M}}=\rho_{\text {air }} u_{*}{ }^{2}$, where $\rho_{\text {air }}$ is the air density. Experiments were performed for 10 to $17 \mathrm{~m} / \mathrm{s}$ centerline wind speeds, the friction velocity, $u_{*}$, varied between 0.46 and 0.73 $\mathrm{m} / \mathrm{s}$; the equivalent wind speeds at the reference height $10 \mathrm{~m} U_{10}$ between 16 and $26 \mathrm{~m} / \mathrm{s}$ (this corresponds to Beaufort number up to 10 in field conditions [10]).

Tab. 1: Air-side logarithmic boundary layer parameters for different fan rotation frequencies $F$.

\begin{tabular}{|c|c|c|}
\hline $\boldsymbol{F} \mathbf{( H z})$ & $\boldsymbol{u}_{*}(\mathbf{m} / \mathbf{s})$ & $\boldsymbol{U}_{\mathbf{1 0}}(\mathbf{m} / \mathbf{s})$ \\
\hline 30 & 0.47 & 16.4 \\
\hline 35 & 0.52 & 18.8 \\
\hline 40 & 0.61 & 21.8 \\
\hline 45 & 0.69 & 24.5 \\
\hline 50 & 0.73 & 26.6 \\
\hline
\end{tabular}

\subsection{High-Speed Video Recording Setup}

The details of the bag-breakup fragmentation were investigated qualitatively and quantitatively using high-speed video recording. Synchronized multiperspective high-speed recordings were captured in shadowgraph configuration: vertical opaque screen behind the scene was illuminated from behind with intensive light source. 
The main shadowgraph recording was carried out horizontally with high-resolution NAC Memrecam HX-3 high-speed digital video camera with Zeiss $100 \mathrm{~mm}$ f/2.0 Makro Classic lens (f/22 aperture was used). Two 100W LED light sources were used as a backlight, and a white opaque screen was located on the opposite from the camera side of the flume. The camera is located at a distance of $60 \mathrm{~cm}$ from the bag-breakup area $(63 \mu \mathrm{m} / \mathrm{px}$ scale $)$ so that the optical axis lies in the plane of the water surface. The shooting speed was $3990 \mathrm{fps}$, the shutter speed was $1 / 50000 \mathrm{~s}$, the image size was $2560 \times 960$ pixels $(161 \times 60 \mathrm{~mm})$.

Additional shooting was done from above with the Optronis CamRecord CR3000x2 camera with Samyang $85 \mathrm{~mm} \mathrm{f} / 1.4$ lens. The camera was located at a distance of $112 \mathrm{~cm}$ from the surface (scale $102 \mu \mathrm{m} / \mathrm{px}$ ). The shooting speed was $1250 \mathrm{fps}$, the shutter speed was $1 / 5000 \mathrm{~s}$, the image size was $1696 \times 720$ pixels $(173 \times 74 \mathrm{~mm})$.

We used the same LED light source for side and top shooting, so only side shooting was made in shadowgraph setup. The side view was used to obtain detailed data on the dynamics of the resulting structures: the shape of the structure before and during bag-breakup, the speed and size of the droplets formed. Top view was only used to control the shape of the structure in the transverse direction.

Records were made for 5 different wind speeds with fan rotation frequencies of 30, 35, 40, 45 and $50 \mathrm{~Hz}$ (centerline wind speed $10 \div 17 \mathrm{~m} / \mathrm{s}$ ). For each wind speed, 9 to 17 records of the bag-breakup were captured. Each recording from the side camera consists of $250 \div 700$ frames $(63 \div 175 \mathrm{~ms})$. Before and after each recording, control measurements of the shape and size of the initial disturbance were made without wind. 


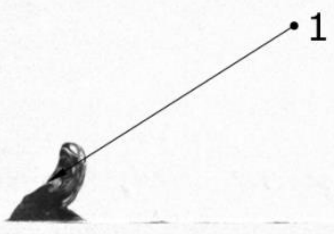

$110 \mathrm{~ms}$

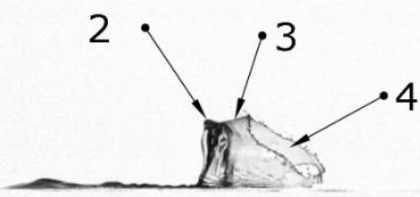

$113 \mathrm{~ms}$

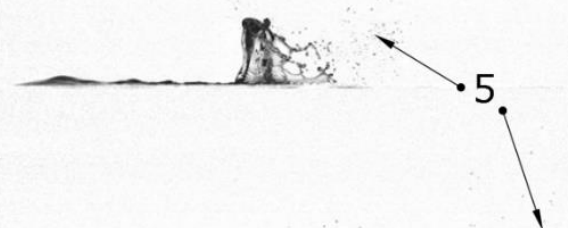

$120 \mathrm{~ms}$

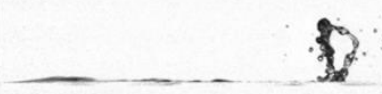

$128 \mathrm{~ms}$<smiles>[As][Te]</smiles>

Fig. 2: Example of images obtained from the side camera (time points 83, 110, 113 and 120 ms) for wind speed $U_{10}=21.8 \mathrm{~m} / \mathrm{s} .1$ - initial disturbance, 2 - rim, 3 - film, 4 - film rupture, 5 - film drops, 6 - rim drops. Full image width $161 \mathrm{~mm}$.

\section{2}

\section{Image Processing}

A study of the obtained video records showed that the generation of spray during the individual bag-breakup was due to two processes: 1) rupture of the film, which leads to the formation of small droplets; 2) fragmentation of the "rim" remaining after the rupture of the liquid film, at which large drops are generated (see Fig. 2). 

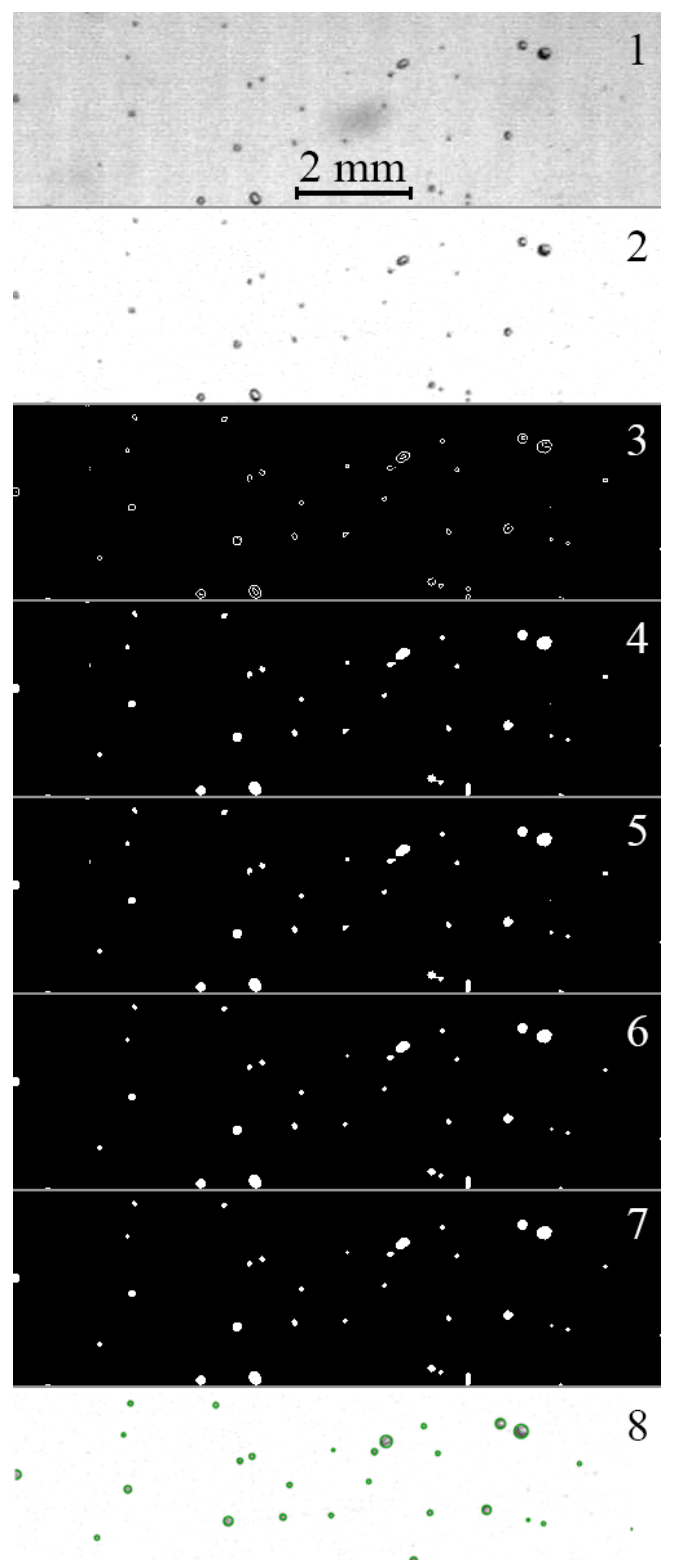

Fig. 3: Image processing sequence for a fragment of frame $\left(U_{10}=21.8 \mathrm{~m} / \mathrm{s}, 113 \mathrm{~ms}\right.$ after film puncture, $81 \mathrm{~mm}$ downwind the initial disturbance, $33 \mathrm{~mm}$ above surface), Green circles - detected droplets

Special software was developed for the processing of side video recordings. It enabled us obtaining detailed data on the dynamics of the resultant structures, such as the shape of the structure at different stages of the rupture, the speed and size of the droplets formed. It utilizes homebrew implementations of feature detection, Particle image velocimetry and particle tracking methods for droplet tacking.

\subsection{Droplet Detection}

At the first stage of droplet trajectories retrieving, an special algorithm was developed, which allows finding the position of all visible droplets on each frame of the record. The image processing sequence is shown in Fig. 3. for a fragment of one frame. This sequence is an evolution of an algorithm previously developed for water surface detection in laser measurements, that is described in details in [11]. First the background is subtracted from initial frame $(1,2)$; edge detection is performed with Sobel operator (3), morphological closing with 3-pixel disk element (4) and subsequent filling of closed areas (5) results in 
binary image of large droplets; noise is suppressed with morphological opening with 1-pixel disk element (6); to preserve small droplets logical 'or' is performed with binarized by threshold initial image (7); positions and sizes of all isolated regions are calculated (8). Larger areas are rejected with their closes neighbors as part of the initial disturbance or "rim". As a result we get position and size of every droplet and some false detections on every frame of side view records (Fig. 4). For images captured with current side view setup this algorithm can only detect droplets larger than $100 \mu \mathrm{m}$, but same algorithm can be used for smaller droplets using video with higher resolution.

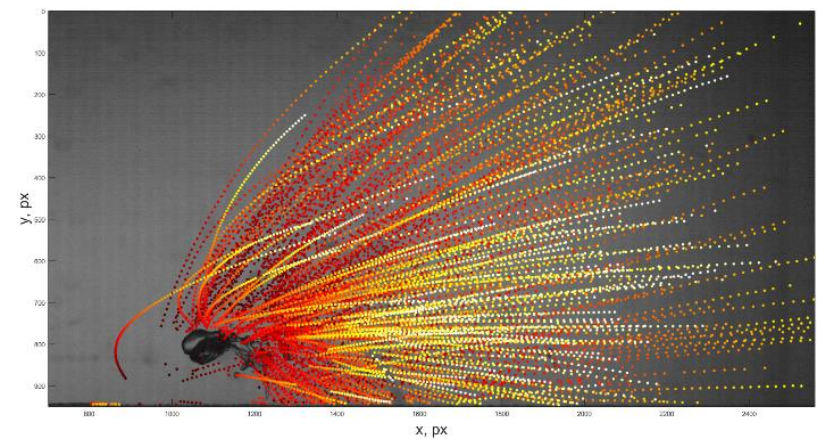

Fig. 4: Position of all droplets found on all frames in one record $\left(U_{10}=21.8 \mathrm{~m} / \mathrm{s}\right)$; color represents frame number. $6.2 \mathrm{~ms}$ after film puncture. Full image width $117 \mathrm{~mm}$.

\subsection{Droplet Velocity Estimates}

In order to facilitate the tracking of droplets, the velocities of droplets were estimated by Particle image velocimetry method (PIV). This was possible due to the fact that most droplets in particular area of image have similar velocities. PIV processing of the images was performed by specially developed software similar to our previous studies of air velocities in marine boundary layer [12]. Successive frames were compared, interrogation window size $128 \times 128$ pixels with $50 \%$ overlapping, only one iteration is used, with tree-point interpolation for CCF maximum. Velocity fields were filtered using maximum and minimum velocity thresholds, then with 2-dimentional median filtering and then were interpolated to position of every droplet of the frame (Fig. 5).

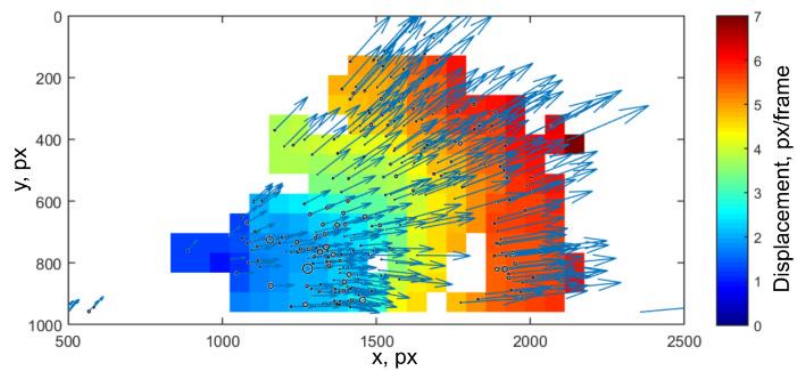

Fig. 5: Approximate velocity field obtained by PIV for equivalent wind speed $U_{10}=21.8$ $\mathrm{m} / \mathrm{s}$. The color represents velocity field, arrows - interpolation to position of each droplet (shown in circles).

\subsection{Droplet Tracking}

In order to retrieve droplet trajectories special tacking algorithm was developed. As droplet density decreases over time we run tacking backward in time: it is easier to separate trajectories if we start with lower density. Starting from the end of the record for every droplet on frame we try to find appropriate droplet on previous frame in the vicinity of its assumed position. 


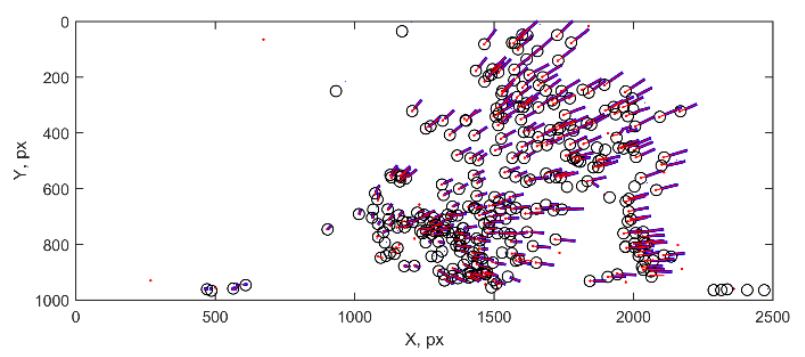

Fig. 6: Example of a trajectory search for equivalent wind speed $U_{10}=21.8 \mathrm{~m} / \mathrm{s}$. Circles shows the search area near the assumed position. Blue lines are the previous 4 points of each trajectory. Red dots positions of all droplets on the frame.

We used two methods for calculation of assumed position: 1) based on interpolated PIV velocity field; 2) based on parabolic extrapolation for coordinated of four previously found points of current trajectory assuming a constant acceleration. A combination of these two methods is used: the first method is used for trajectories containing less than 4 known points, the average with weights between two methods is used otherwise. Trajectory data, the last found point of which is not more than three frames from a given one, is used for each frame. Thus, if a drop has not been detected on one or two consecutive frames, the trajectory will still be constructed. The trajectory search stops when there are no droplets found in the vicinity of 20 pixels from the expected position or the radius of the droplet found is more than 3 times different from the current one. If two trajectories find the same drop, the latter is assigned to the trajectory, the distance to the supposed point of which is smaller. The use of four points for polynomial extrapolation allows taking into account the scatter of the calculated coordinates. If it is too large, then the last found point of the trajectory is neglected. The example of droplet tracking is shown on Fig. 6.

Some of trajectories are rejected as false detection. Motionless trajectories (with median displacement less than 0.001 pixels per frame) and trajectories shorter than 10 frames are rejected as noise. This algorithm can result in trajectories that are non-overlapping parts of a single real trajectory (in the case when tracking loses a droplet and then finds it and starts a new trajectory). In order to combine such trajectories into one, for each non-intersecting in time pair of trajectories, the standard deviation of the found positions and the polynomial extrapolation was calculated. In case of a deviation below the threshold, the trajectories were combined into one. The described algorithm can be performed in several iterations: On each iteration assigned to trajectories droplet detections are excluded. This algorithm enables assigning more than $75 \%$ of droplets found to trajectories for most part for the experimental condition (and significant part missed droplets are false detected ones) and getting more than 500 separate trajectories for some of the records. The example of retrieved trajectories is shown in Fig. 7.

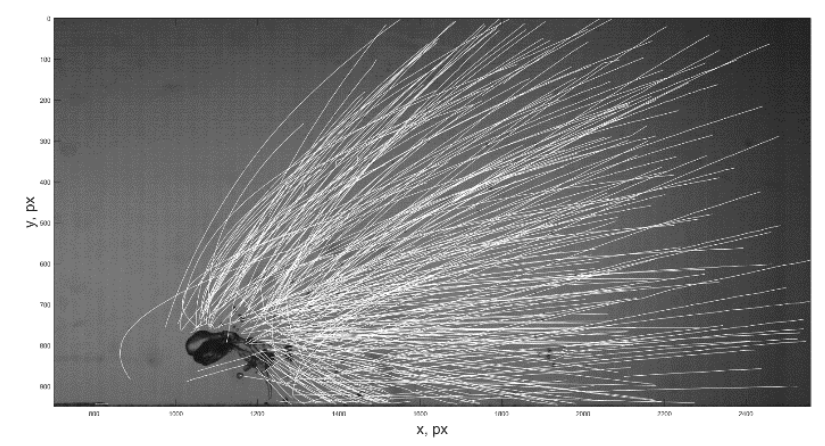

Fig. 7: All trajectories (white) found in one record $\left(U_{10}=21.8 \mathrm{~m} / \mathrm{s}\right)$. Example frame is $6.2 \mathrm{~ms}$ after film puncture. Full image width $117 \mathrm{~mm}$. 


\section{Conclusion}

A special system that allows modeling under controlled conditions a single event of bagbreakup fragmentation, which is the dominant process of spray generation during wind-wave interaction, was developed. We used the approach of forced generation of the separate bagbreakup event in a dried high-speed wind-wave flume with water reservoir installed under the working section.

To obtain information on the characteristics of the spray, high-speed shooting in shadowgraph configuration was used and special software was developed to identify the droplets on the images and track their trajectories based on the combination of PIV and reversed in time particle tracking, utilizing the fact of reducing density of droplets in the image over time starting from the moment of fragmentation. The data obtained by this method in combination with the statistics of the occurrence of "bags" will be used to construct the empirical function of spray generation.

\section{Acknowledgments}

Carrying out experiments themselves was supported by Russian Science Foundation (Agreement No. 14-17-00667); designing of methods of measurements including: optical and visualization scheme, methods of measurements of the air flow and wave field parameters were supported by Russian Foundation of Basic Research (No 18-77-00074); the development of the software for video processing was supported by the Grant of the President No. MK2041.2017.5.

\section{Literature}

[1] ANDREAS, E. L.; EMANUEL, K. A.: Effects of Sea Spray on Tropical Cyclone Intensity. Journal of the Atmospheric Sciences. 2001, Vol. 58, pp. 3741-3751. DOI: 10.1175/1520-0469(2001)058<3741:EOSSOT>2.0.CO;2

[2] ANDREAS, E. L.: Fallacies of the Enthalpy Transfer Coefficient over the Ocean in High Winds. Journal of the Atmospheric Sciences. 2011, Vol. 68, pp. 1435-1445. DOI: $10.1175 / 2011 \mathrm{JAS} 3714.1$

[3] BAO, J.-W.; FAIRALL, C. W.; MICHELSON, S. A.; BIANCO, L.: Parameterizations of Sea-Spray Impact on the Air-Sea Momentum and Heat Fluxes. Monthly Weather Review. 2011, Vol. 139, pp. 3781-3797. DOI: 10.1175/MWR-D-11-00007.1

[4] SOLOVIEV, A. V.; LUKAS, R.; DONELAN, M. A.; HAUS, B. K.; GINIS, I.: The airsea interface and surface stress under tropical cyclones. Scientific Reports. 2014, Vol. 4, Article No. 5306. DOI: $10.1038 / \mathrm{srep05306}$

[5] TAKAGAKI, N. et al.: Strong correlation between the drag coefficient and the shape of the wind sea spectrum over a broad range of wind speeds. Geophysical Research Letters. 2012, Vol. 39, Issue 23. DOI: 10.1029/2012GL053988

[6] TAKAGAKI, N.; KOMORI, S.; SUZUKI, N.; IWANO, K.; KUROSE, R.: Mechanism of drag coefficient saturation at strong wind speeds. Geophysical Research Letters. 2016, Vol. 43, Issue 18, pp. 9829-9835. DOI: 10.1002/2016GL070666

[7] ANDREAS, E. L.: A review of spray generation function for the open ocean in Atmosphere. In: Perrie, W. (ed.), Ocean Interactions Volume 1. 2002, pp. 1-46.

[8] TROITSKAYA, Y. et al.: Bag-breakup fragmentation as the dominant mechanism of sea-spray production in high winds. Scientific Reports. 2017, Vol. 7, Article No. 1614. DOI: $10.1038 / \mathrm{s} 41598-017-01673-9$ 
[9] TROITSKAYA, Y. I. et al.: Laboratory and theoretical modeling of air-sea momentum transfer under severe wind conditions. Journal of Geophysical Research: Oceans. 2012, Vol. 117, Issue C11. DOI: 10.1029/2011JC007778

[10] NATIONAL METEOROLOGICAL LIBRARY in conjunction with the MET OFFICE'S NATIONAL CLIMATE INFORMATION CENTRE: National Meteorological Library and Archive Fact sheet 6 - The Beaufort Scale. [online]. 2010. Available from

WWW: http://www.metoffice.gov.uk/binaries/content/assets/mohippo/pdf/s/j/10_0425_factsheet 6_beaufort.pdf

[11] SERGEEV, D. A.; KANDAUROV, A. A.; VDOVIN, M. I.; TROITSKAYA, Y. I.: Studying of the surface roughness properties by visualization methods within laboratory modeling of the atmospheric-ocean interaction, Sci Vis. 2015, Vol. 7, Issue 5, p. 109.

[12] KANDAUROV, A. A.; TROITSKAYA, Y. I.; SERGEEV, D. A.; VDOVIN, M. I.; BAIDAKOV, G. A.: Average velocity field of the air flow over the water surface in a laboratory modeling of storm and hurricane conditions in the ocean. Izvestiya, Atmospheric and Oceanic Physics. 2014, Vol. 50, Issue 4, pp 399-410. DOI: $10.1134 / \mathrm{S} 000143381404015 \mathrm{X}$ 


\section{ZKOUMÁNÍ STIMULOVANÝCH PROCESŮ ROZTRŽENÍ VAKU V LABORATORNÍM MODELU INTERAKCÍ VLN ZPŮSOBENÝCH VĚTREM}

Laboratorní experiment pro identifikaci mechanizmů tvorby kapiček pěny $\mathrm{v}$ mořské atmosférické hraniční vrstvě, kdy silný vítr odtrhne vodu z hřebene vln, byl prováděn na vysokorychlostním vlně IAP RAS. Hlavním mechanismem, který je odpovědný za tvorbu kapiček pěny, je fragmentace roztrženého vaku a drobné poruchy, které vznikají na rozhraní vzduch-voda pod silným větrem. Tato práce se soustřed’uje na zkoumání jednotlivých případů roztržení vaků, ke kterým došlo v suchém vysokorychlostním větru. Podrobnosti fragmentace roztržení vaků byly zkoumány kvalitativně a kvantitativně pomocí synchronizovaného multiperspektivního vysokorychlostního záznamu videa v radiografické konfiguraci.

\section{DiE ERFORSCHUNG DER STIMULIERTEN PROZESSE DES REIßENS DES SACKS IM LABORMODELL DER INTERAKTIONEN VON WINDERZEUGTEN WELLEN}

Das Laborexperiment zur Identifizierung der Mechanismen der Bildung von Schaumtropfen in der Grenzschicht zwischen Meer und Atmosphäre, wobei starker Wind das Wasser von den Wellenkämmen losreißt, wurde im Hochgeschwindigkeitswind der Welle IAP-RAS-Welle durchgeführt. Der Hauptmechanismus, welcher für die Bildung von Schaumtropfen verantwortlich ist, besteht in der Fragmentierung des gerissenen Sacks und in kleinen Störungen, welche an der Luft-Wasser-Grenze unter starkem Wind entstehen. Diese Arbeit konzentriert sich auf die Erforschung der einzelnen Fälle des Reißens der Säcke, zu welchem es in trockenem Hochgeschwindigkeitswind kam. Die Details der Fragmentierung des Reißens der Säcke wurden qualitativ und quantitativ mit Hilfe einer synchronisierten multiperspektiven Hochgeschwindigkeitsaufnahme des Videos in radiografischer Konfiguration untersucht.

\section{BADANIE STYMULOWANYCH PROCESÓW BAG-BREAKUP W LABORATORYJNYM MODELU INTERAKCJI FAL WYWOŁANYCH WIATREM}

Doświadczenie laboratoryjne mające na celu zidentyfikowanie mechanizmów powstawania kropli piany w atmosferycznej warstwie granicznej nad morzem, gdy silny wiatr odrywa wodę z grzbietu fal, przeprowadzano w kanale falowo-wiatrowym o szybkim przepływie IAP RAS. Głównym mechanizmem odpowiedzialnym za powstawanie kropli piany jest fragmentacja rozerwanego worka (bag-breakup) i drobne uszkodzenia, które powstają na granicy powietrze-woda pod wpływem silnego wiatru. Niniejsze opracowanie skupia się na badaniu poszczególnych przypadków efektu bag-breakup, które wystąpiły pod wpływem szybkiego przepływu suchego powietrza. Fragmentacja była szczegółowo badana zarówno pod względem jakościowym, jak i ilościowym przy pomocy zsynchronizowanego wieloperspektywicznego szybkiego zapisu wideo w konfiguracji radiograficznej. 